\title{
Terroir of the Tri Morave Wine Region (Serbia) as a Basis for Producing Wines with Geographical Indication
}

\author{
Nemanja TomićA*, Jelena KokovićB, Darko Jakšićc, Jordana Ninkov'D, \\ Jovica Vasin' ${ }^{\text {, Marko Malićanin }}{ }^{\mathrm{E}}$, Slobodan B. Marković ${ }^{\mathrm{A}}$ \\ Received: March 6, 2017 | Revised: May 18, 2017 | Accepted: May 29, 2017 \\ DOI: 10.5937/GeoPan1703166T
}

\begin{abstract}
The Tri Morave wine region is the largest wine growing region in Serbia with nine vineyard regions and a total surface area of $286,929.90$ ha. It includes the areas around three big rivers in Central Serbia; the wide lower basin of the Zapadna Morava River, the lower basin of the Južna Morava River and the wider upper basin of the Velika Morava River. The unique terroir of this region is reflected in the diversity of altitudes and terrain inclination that gives it its specific character and recognition and provides an excellent basis for producing wines with geographical indication. The main goal of this paper is to present all of the essential elements of terroir in this region as well as their interaction and influence on grapevines and wine production.
\end{abstract}

Keywords: Terroir, Tri Morave, Wine, Geographical indication, Serbia

\section{Introduction}

The term and the concept of terroir is a much discussed topic that has caused numerous disagreements amongst vineyard and wine experts of the new and old world for many decades. Is it just a marketing trick by the French as it is claimed by certain authors, or do natural factors such as terrain, climate, soil and numerous other factors really have such a large impact on the tastes and aromas found in wine?

In the strictest definition, terroir is French for 'land' or 'soil' but in the language of wine it means much more. This powerful geographical concept encompasses the belief that each wine derives its characteristics from the environment in which the grapes are grown. There are many variables influencing terroir.
Among the most important is physical geography including climate, microclimate, air flow, exposure to the sun, water drainage, geology, topography, altitude and soil (Dougherty, 2012).

The general assembly of the International organization of vine and wine (Resolution OIV/Viti 333/2010) defined terroir as a concept which refers to an area in which collective knowledge of the interactions between the identifiable physical and biological environment and applied vitivinicultural practices develops, providing distinctive characteristics for the products originating from this area. Terroir includes specific soil, topography, climate, landscape characteristics and biodiversity features.

One of the general misconceptions about the concept of terroir is that it affects the quality of wine. In its

\footnotetext{
A University of Novi Sad, Faculty of Sciences, Department of Geography, Tourism and Hotel Management, Trg Dositeja Obradovića 3, 21000 Novi Sad, Serbia; airtomic@gmail.com

B University of Novi Sad, Faculty of Agriculture, Trg Dositeja Obradovića 8, 21000 Novi Sad, Serbia

C Ministry of Agriculture and Environmental Protection, Nemanjina 22-26, 11000 Belgrade, Serbia

D Institute of Field and Vegetable Crops, Maksima Gorkog 30, 21000 Novi Sad, Serbia

E Rubin AD, Nade Marković 57, 37000 Kruševac, Serbia

* Corresponding author: Nemanja Tomić, e-mail: airtomic@gmail.com
} 
origin, terroir has little to do with wine quality. It merely means that wines made from grapes grown in different places vary in aroma and flavour characteristics. Terroir refers to complex interactions between all of the physical aspects of geology, soils, climate, geomorphology and vegetation that combine to create a particular 'place' where grapes are grown (Unwin, 2012).

According to Burns (2012) there are seven main factors that affect the taste of a wine. These factors include the grape variety, geology and resulting soils, climate, soil hydrology, the physiography of the site, the winemaker and vineyard management techniques. The first five of these factors comprise what the French call terroir or 'the taste of the place'.

Terroir is therefore the sum of all of the environmental factors which make wine a unique agricultural product. The smaller the geographic unit, the more important is the terroir. The larger the area, the less important terroir is as a distinctive characteristic.

Each vineyard has a unique and distinct combination of climate, topography and soil type which all together shape the character of the vines that grow there and the grapes that they yield. The choices man makes for their cultivation, and for the subsequent transformation of the grapes into wine, reflects aspects of this distinct place.

Geographical indications (GI) are common to all wine regions and are a common feature on wine labels today. The main reason behind this is that the area where the grapes are grown has a defining influence on the style, quality and flavour of the wine. A vineyard that produces wine with GI is designated as an area within a country. Such an area can be quite large and cover an entire region (e.g. Burgundy) or it can be very small and be no more than a single vineyard. In order for the consumers to get what they payed for, the use of geographical indications is strictly controlled. This ensures that the wine is made from the grapes grown in the location stated on the label. The rules and regulations are very complex and they vary from country to country (Dougherty, 2012)

The main goal of this paper is to present the terroir of the Tri Morave wine region in Serbia as a basis for making wines with GI.

\section{The system of geographical indications for wine in Serbia}

Emphasizing the quality and characteristics of wine from certain regions as well as the use of geographical indications have a long tradition in Serbia. Law regulations related to the production of wine with geographical indications date back to the first half of the $14^{\text {th }}$ century. Geographical indications such as Metohija, Vranje, Župa, Ritopek, Šumadija, Srem have been used for centuries. Evidence than vine cultivation has been present in Serbia for a long time can be seen in the names of grape varieties such as Skadarka, Prokupac, Smederevka and some others (Stojanović, Toskić, 1948) which were named after places or regions where they were intensively grown and showed the best results. The modern use of geographical indications and production control of wines with geographical indications has been regulated from 1929 which places Serbia in the group of countries with a long tradition when it comes to these issues (Ivanišević et al., 2015; Jakšić et al., 2015).

Today, Serbia is a country that is heading towards the EU and it has adjusted its laws and regulations related to geographical indications of wines in accordance with EU regulations. According to the current wine law, wines in Serbia are classified as wines without geographical indications (table wines) and wines with geographical indications which are further divided as regional wines/G.I. wines (P.G.I. wines in the EU) and quality wines with geographical indications (P.D.O. in the EU). The latter have two sub-categories, K.P.K. (short in Serbian for 'controlled origin and quality') and K.G.P.K. (short in Serbian for 'controlled and guaranteed origin and quality') for top quality wines.

Besides geographical indications in accordance with the EU, there are also additional labels for wines with geographical indications. These labels represent stamps of guaranteed quality and have different colours depending on the quality level. Green stamps are for regional wines (G.I. wines), red stamps are for wines with controlled origin and quality (K.P.K.) while the purple ones indicate top quality wines (K.G.P.K.).

\section{Study area}

The Tri Morave wine region includes the areas around three big rivers in Central Serbia, the wide lower basin of the Zapadna Morava River, the lower basin of the Južna Morava River and the wider upper basin of the Velika Morava River. Moving away from the river beds of these rivers, after flatter and then hilly landscapes this region is mostly surrounded by mountains. The Gledić and Bešnjaja mountains rise from the West and North, Goč, Kopaonik, Željin and Jastrebac from the South and Beljanica, Kučaj, Rtanj and Ozren mountains from the East. In the central part of the region, the Juhor Mountain stretches in a north-south direction and it interrupts the area suitable for vine cultivation. It is the diversity of altitudes and terrain inclination in this region (river plains, hills, mountain tops) that gives it its specific character and recognition. 


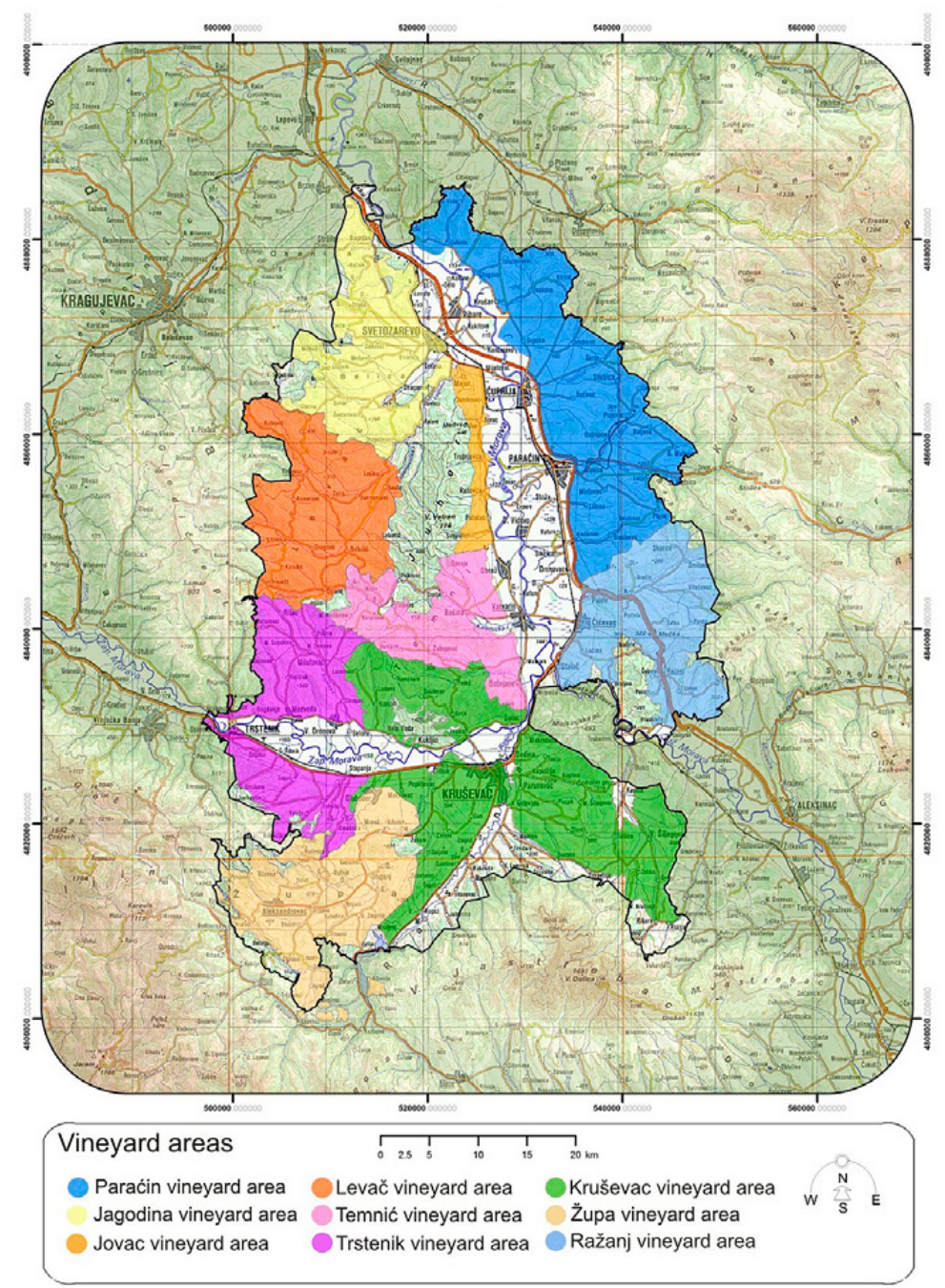

Figure 1. Vineyard areas of the Tri Morave wine region Source: Ivanišević et al., 2015 (modified by authors)

This region is the largest wine growing region in Serbia with a surface area of $286,929.90$ ha. It occupies the territory of 12 municipalities located in three counties: Jagodina, Ćuprija, Paraćin, Rekovac (Pomoravlje County), Trstenik, Varvarin, Ćićevac, Kruševac, Aleksandrovac, Brus (Rasina County), Ražanj and Aleksinac (Niš County).

Based on research by Ivanišević et al. (2015) there are nine vineyard regions (Paraćin, Jagodina, Jovac, Levač, Temnić, Trstenik, Kruševac, Župa, Ražanj) within the Tri Morave wine growing region which make up $70.39 \%$ of this wine regions total surface area $(201,977.51 \mathrm{ha})$. Several areas in the region are less suitable for grape growing and are not classified as vineyard areas. These include river valleys of the Zapadna Morava, Rasina, Velika Morava and a smaller part around the right bank of the Južna Morava River. Besides these areas, there are also several others located at higher altitudes in the central, western, southwestern and southern part of the wine growing region (Figure 1).
The importance of this wine region can be seen through the fact that approximately one third of the total surface area under vineyards in Serbia is located in this region alone. According to the agricultural census from 2012, the Tri Morave wine region has $7,528.76$ ha of vineyards from which 1367.54 ha include table varieties and 6161.22 ha include wine varieties. The vineyards are mainly concentrated in the municipalities of Trstenik (2,00o ha), Kruševac (2,000 ha) and Aleksandrovac (1,500 ha). According to the data from the national vineyard registry, this region currently has 1,601 registered grape producers which is $46.4 \%$ of all registered grape producers in Serbia (Jakšić, 2016).

\section{Terroir of the Tri Morave wine region}

As it was explained before, the concept of terroir includes many aspects related to physical geography as well as their interactions with one another. The main factors include topographical features, climate char- 


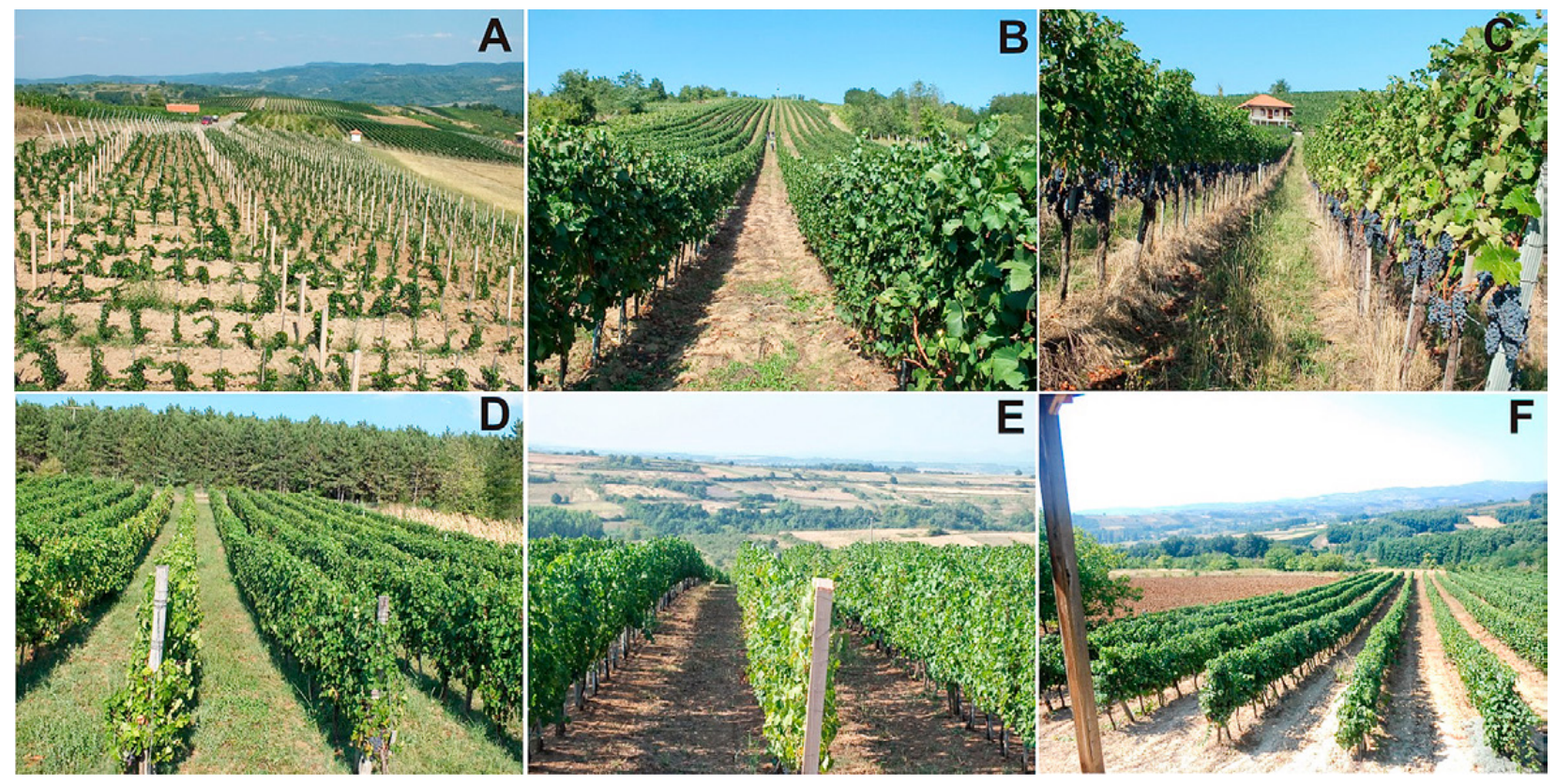

Figure 2. Vineyards of the Tri Morave wine region: (A) Lastar winery vineyards in Levač. (B) Stemina winery vineyards in Trstenik. (C) Milosavljević winery vineyards at Bučje (Trstenik). (D) Rajić winery vineyards at Glavica (Paraćin). (E) Temet winery vineyards at Lozovik (Jagodina). (F) Miletić winery vineyards at Oparić (Levač).

Photos: Brankica Ćurčić

acteristics, geology and geomorphology of the area as well as soil properties and grapes. This chapter will focus on the most important elements of these factors in the Tri Morave wine region.

\section{Topographical features}

When it comes to topographical features of a vineyard area, terrain inclination is a key factor as it affects the solar exposure of a vineyard as well as soil drainage. The beneficial influences of sunward-angled sites on microclimate include enhanced exposure to solar photosynthetic and heat radiation, earlier soil warming, diminished frost severity, and improved drainage. This means that the photosynthetic potential of grapevines may be increased, fruit ripening advanced, berry colour and sugar-acid balance improved, and the growing season extended. Microclimatic disadvantages include increased potential for soil erosion, nutrient loss, water stress, and early loss of snow cover. The potential for bark splitting during the winter is increased, and cold acclimation may be lost prematurely. As the slope increases, the performance of vineyard activities becomes progressively more difficult - eventually making mechanization impossible. The net benefit of a sloped site depends on its inclination (vertical deviation), aspect (compass orientation), latitude, and soil type, as well as cultivar and viticultural choices. The benefits of an inclined location become progressively important with increased vineyard latitude or altitude. Not surprisingly, Germany, the most northerly major wine-producing region in Europe is renowned for its steep, south-facing vineyards (Jackson, 2008).

\section{Longitude and altitude}

The Tri Morave wine region is located between $43^{\circ} 21^{\prime}$ $\mathrm{N}$ and $44^{\circ} 07^{\prime} \mathrm{N}$. Around one third (30.57 \%) of its vineyards is located $200 \mathrm{~m}$ or $300 \mathrm{~m}$ above sea level (asl). However, $55.15 \%$ of vineyards are located between $300 \mathrm{~m}$ and $400 \mathrm{~m}$ asl which is much more than the percentage of vineyards at the same altitude on the national level (32.46\%). The percentage of vineyards above $400 \mathrm{~m}$ and $500 \mathrm{~m}(10.65 \%)$ in this region is also larger than on the national level (6.14\%). This layout of vineyards in the region at different altitudes certainly has an effect on grape ripening as well as on some specific features typical mainly for this region (Jakšić, 2016).

\section{Terrain inclination}

Analysis of data collected by applying GIS technology shows that most vineyards in the region are located on slopes. The majority of them (49.31 \%) are on slopes that have a terrain incline bigger than 5 to 10 degrees. About $10 \%$ is on slopes with an incline of 10 to 15 degrees and about $36 \%$ (10 \% less than on the national level) is located on flatter terrain (between o and 5 degrees).

Considering that soil inclination has a major effect on the thermal regime, insolation and soil moisture, this kind of terrain with different degrees of inclines is a favourable factor for vine and grape growing as well as making high quality wine (Avramov, 1991). 


\section{Solar exposure}

Vineyards of the Tri Morave wine region are mostly located on the southern (20.47\%), south-western $(19.8 \%)$, and south-eastern exposure (18.76\%), followed by eastern (12.67 \%) and western exposures (7.41 $\%)$. Vineyards on north-eastern, northern and northwestern exposures occupy $18.75 \%$ while $2.15 \%$ is located on flat surfaces. This high percentage of 'warmer' and sunnier exposures indicates to a favourable vineyard structure in this region when it comes to this important factor (Jakšić, 2016).

\section{Climate characteristics}

For all agricultural enterprises climate plays a dominant role in influencing whether a crop is suitable to a given region, largely controlling crop production and quality, and ultimately driving economic sustainability. In viticulture and wine production, climate is arguably the most critical aspect in ripening fruit to achieve optimum characteristics to produce a given wine style. For wine drinkers the most easily identifiable differences in wine styles come from climate: the general characteristics of wines from a cool climate versus those from a hot climate. Varieties that are best suited to a cool climate tend to produce wines that are more subtle, with lower alcohol, crisp acidity, a lighter body, and typically bright fruit flavours, while those from hot climates tend to be bigger, bolder wines with higher alcohol, soft acidity, a fuller body, and more dark or lush fruit flavours. Geology or soil does not produce these general differences, their impact is found in the subtle differences and/or expres- sion of fruit characteristics and wine styles within the same climate or region (Jones, Goodrich, 2008).

\section{Air temperature}

According to average monthly air temperatures, the coldest month in this region is January while July is the warmest (Figure 3). The average monthly temperature in September (when most of the grapes ripen) is the same as in the Vranje wine region $\left(17.2^{\circ} \mathrm{C}\right)$. This is slightly higher than the temperatures in Knjaževac $\left(16.7^{\circ} \mathrm{C}\right)$, Subotica $\left(17.1^{\circ} \mathrm{C}\right)$ and Leskovac $\left(17.1^{\circ} \mathrm{C}\right)$ and slightly lower than in Šumadija $\left(17.4^{\circ} \mathrm{C}\right)$, Southern Banat $\left(17.5^{\circ} \mathrm{C}\right)$, Negotin $\left(17.9^{\circ} \mathrm{C}\right)$, Niš $\left(18^{\circ} \mathrm{C}\right)$, Srem $(18.1$ $\left.{ }^{\circ} \mathrm{C}\right)$, Belgrade $\left(18.4{ }^{\circ} \mathrm{C}\right)$ and Southern Metohija $\left(18.4{ }^{\circ} \mathrm{C}\right)$ wine regions during the same period.

The average monthly maximum air temperature is the lowest in January $\left(4.5^{\circ} \mathrm{C}\right)$ and highest in August $\left(28.2^{\circ} \mathrm{C}\right.$ ) (Figure 2). Even though the temperature is moderately high, it is somewhat more favourable than in some other regions in Serbia where maximum temperatures are recorded in July which can stress the vines sooner due to high temperatures. The average maximum temperature in September is $23.9^{\circ} \mathrm{C}$ which is higher than in Subotica $\left(22.9^{\circ} \mathrm{C}\right)$, Srem $(23.3$ $\left.{ }^{\circ} \mathrm{C}\right)$, Southern Banat $\left(23.6^{\circ} \mathrm{C}\right)$, Belgrade $\left(23.7^{\circ} \mathrm{C}\right)$ and Šmadija $\left(23.8^{\circ} \mathrm{C}\right)$ and lower than in Southern Metohija $\left(24^{\circ} \mathrm{C}\right)$, Knjaževac $\left(24.2^{\circ} \mathrm{C}\right)$, Negotin $\left(24.2^{\circ} \mathrm{C}\right)$, Leskovac $\left(24.3^{\circ} \mathrm{C}\right)$ and Niš $\left(24.7^{\circ} \mathrm{C}\right)$ wine regions.

The average monthly minimum air temperature is lowest in January $\left(-4{ }^{\circ} \mathrm{C}\right)$ and highest in July (14.8 ${ }^{\circ} \mathrm{C}$ ) (Figure 2). The average minimum air temperature in September is $10.4^{\circ} \mathrm{C}$, the same as in the Vran-

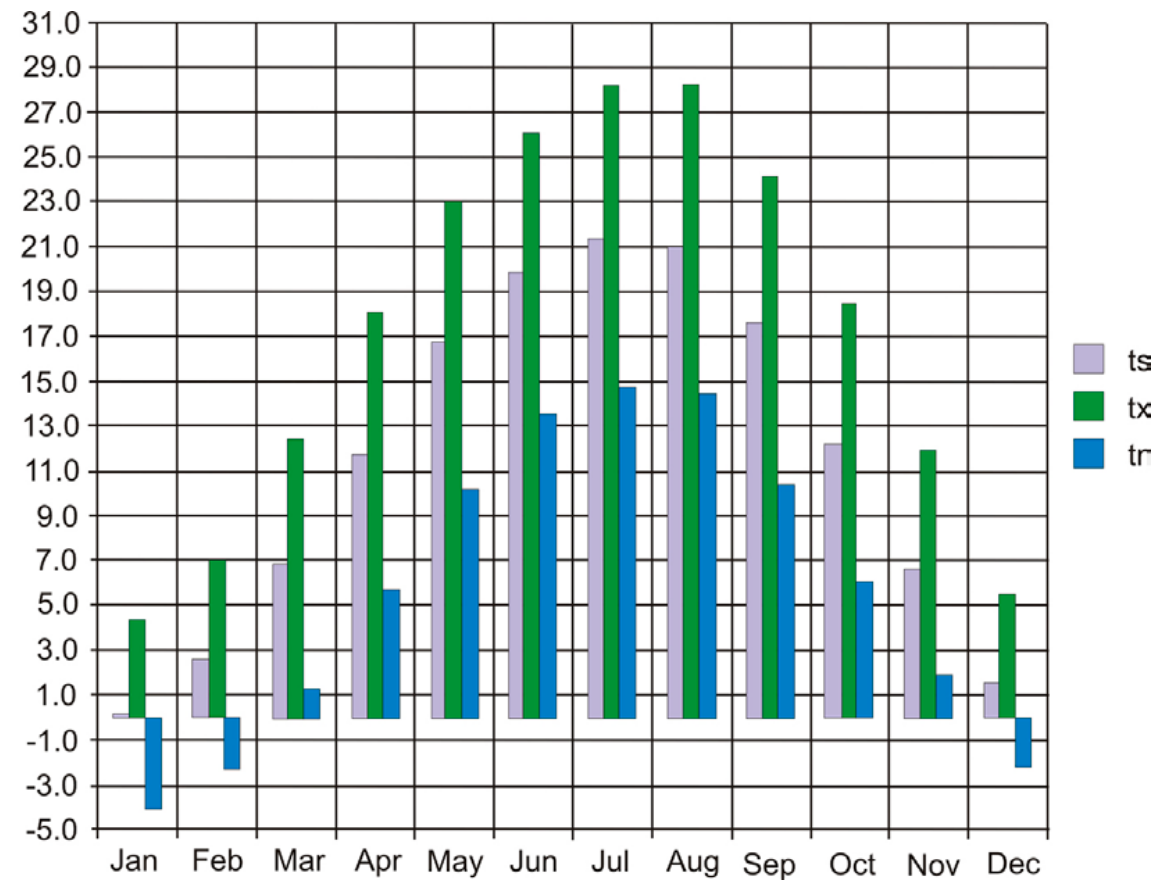

Figure 3. Average monthly air temperatures, average monthly maximum air temperatures and average monthly minimum air temperatures $\left({ }^{\circ} \mathrm{C}\right)$ 
je wine region. It is higher than in Knjaževac $\left(9.2^{\circ} \mathrm{C}\right)$ and Leskovac $\left(9.9^{\circ} \mathrm{C}\right)$, and lower than in Šumadija $\left(11{ }^{\circ} \mathrm{C}\right)$, Subotica $\left(11.2{ }^{\circ} \mathrm{C}\right)$, Niš $\left(11.3^{\circ} \mathrm{C}\right)$, Southern Banat $\left(11.4^{\circ} \mathrm{C}\right)$, Negotin $\left(11.5^{\circ} \mathrm{C}\right)$, Southern Metohija $(12.7$ $\left.{ }^{\circ} \mathrm{C}\right)$, Srem $\left(12.8^{\circ} \mathrm{C}\right)$ and Belgrade $\left(13.2^{\circ} \mathrm{C}\right)$ wine regions.

The average annual air temperature (for the last 50 years) in the region is $11.4^{\circ} \mathrm{C}$ which is higher than in Knjaževac $\left(11^{\circ} \mathrm{C}\right)$, Subotica $\left(11.1^{\circ} \mathrm{C}\right)$ Vranje $\left(11.2^{\circ} \mathrm{C}\right)$ and Leskovac $\left(11.3^{\circ} \mathrm{C}\right)$ wine regions and lower than in Negotin $\left(11.6^{\circ} \mathrm{C}\right)$, Vršac $\left(11.6^{\circ} \mathrm{C}\right)$, Šumadija $\left(11.7^{\circ} \mathrm{C}\right)$, Niš $\left(12.1^{\circ} \mathrm{C}\right.$ ), Vlasotince vineyard region (Leskovac wine region) $\left(12.1^{\circ} \mathrm{C}\right)$, Srem $\left(12.1^{\circ} \mathrm{C}\right)$, Belgrade $(12.6$ ${ }^{\circ} \mathrm{C}$ ) and Southern Metohija $\left(12.4^{\circ} \mathrm{C}\right)$. The average maximum annual temperature is $17.1^{\circ} \mathrm{C}$ while the minimum is $5.7^{\circ} \mathrm{C}$ (Jakšić, 2016).

The average annual air temperature is higher than the one analyzed by Nakalamić and Marković (2009) for the period from 1961 to 1995 . The average annual air temperature for that period was $10.9{ }^{\circ} \mathrm{C}$ which indicates to gradual climate change and warming in the region. This is also confirmed when comparing the average air temperature during the vegetation period. This parameter is also higher $\left(17.1^{\circ} \mathrm{C}\right)$ than the value from the analysis by Nakalamić and Marković (16.6 ${ }^{\circ} \mathrm{C}$ ) for the period between 1961 and 1995.

\section{Precipitation}

The average monthly precipitation (Figure 4) in the Tri Morave wine region between 1961 and 2010 is the lowest in February $(40.4 \mathrm{~mm})$ and the highest during June $(77.3 \mathrm{~mm})$. This data is in accordance with the data analyzed by Nakalamić and Marković (2009) for the period from 1961 to 1995 in Kruševac.
The average monthly precipitation during September is $49.9 \mathrm{~mm}$ which is a bit higher than in the data of Nakalamić and Marković from 2009 (43 mm) but still suitable from the aspect of grape ripening with low risk of grape rotting.

The average annual precipitation in the region is $644 \mathrm{~mm}$ and it is higher than in most other regions (Subotica - $560.2 \mathrm{~mm}$, Srem - $587.6 \mathrm{~mm}$, Knjaževac $592.3 \mathrm{~mm}$, Niš - $593.5 \mathrm{~mm}$, Vranje - $605 \mathrm{~mm}$, Leskovac - $618.8 \mathrm{~mm}$, Negotin - $632.2 \mathrm{~mm}$, Šumadija - 634.2 $\mathrm{mm}$ ). There are only three wine regions in Serbia with higher average annual precipitation, Southern Banat $(655.4 \mathrm{~mm})$, Belgrade $(698.1 \mathrm{~mm})$ and Southern Metohija (779.1 mm).

The average precipitation during the vegetation period (April-October) is $406 \mathrm{~mm}$ which is higher than in Niš (362.7 mm), Knjaževac (367.4 mm), Subotica $(369.4 \mathrm{~mm})$, Negotin $(369.6 \mathrm{~mm})$, Vranje $(370.7 \mathrm{~mm})$, Leskovac $(372.2 \mathrm{~mm})$ and Srem $(382.2 \mathrm{~mm})$ and lower than in the regions of Šmadija (418.6 mm), Southern Metohija (423 mm), Southern Banat $(438.9 \mathrm{~mm})$ and Belgrade (441.4 mm).

\section{Climate characteristics of the Tri Morave wine region according to basic bioclimatic indexes of OIV (International organization of vine and wine)}

The average air temperature in the Tri Morave wine region during the vegetation period is $17.1^{\circ} \mathrm{C}$ confirming that the region has favourable climatic conditions for vine growing.

The heat summation period (April-October), also known as Winkler index is 1571.5 placing the Tri Morave wine region in the II zone according to Win-

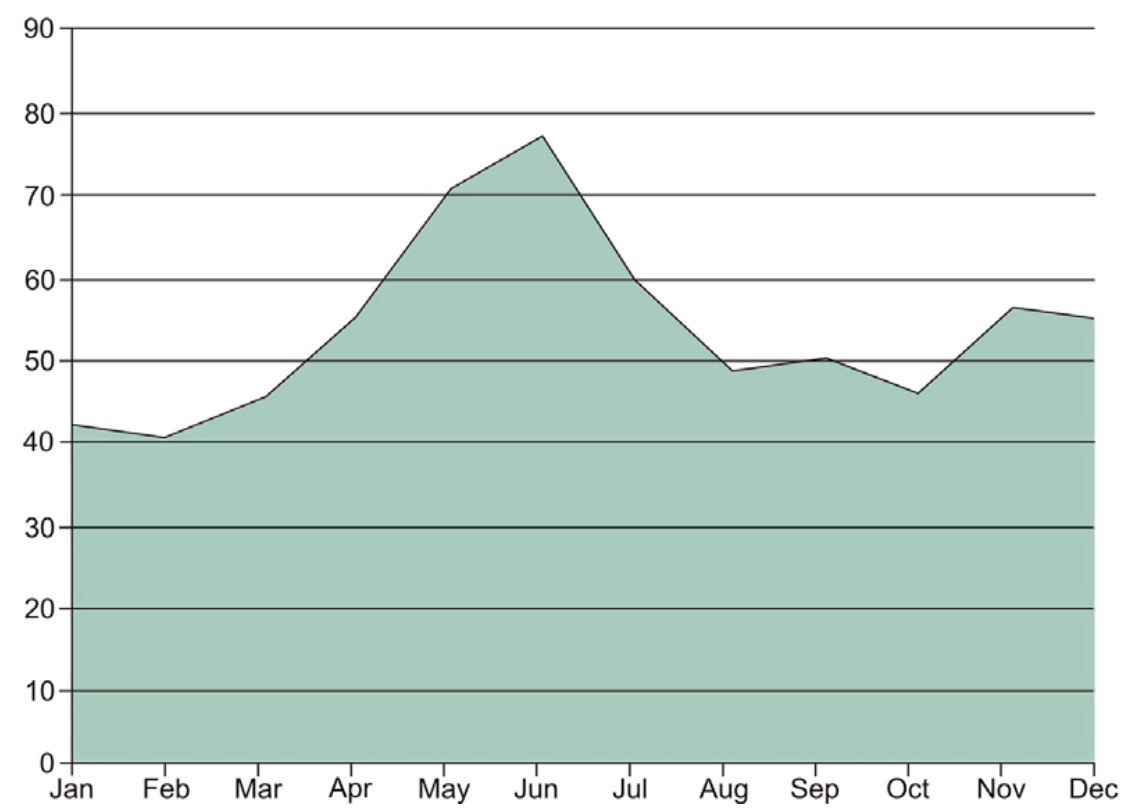

Figure 4. Average monthly precipitation $(\mathrm{mm})$ 
kler (Winkler, 1974).Other regions throughout the world that belong to this zone include vineyard areas around Budapest (Hungary), Bucharest (Romania) as well as the area of Napa Valley (USA). The Winkler Index for the fifty year period (1961-2010) is higher than the index from 1961 to 1995 (1421) meaning that there was an increase in the last fifteen years of the analyzed period. Also, the Winkler index for the fifty year period in Jagodina is 1680.6, putting the area around Jagodina into the warmer III zone according to the Winkler scale. The Zapadna Morava River valleywith most of its part also belongs to this zone. However, considering that most vineyards are located at higher altitudes (200-500 m) and not in these warmer zones it is safe to say that the Winkler Index is lower in those places (Jakšić, 2016).

Huglin (heliothermal) index (April-October) is 2130 placing the Tri Morave wine region in HI+1 group of wine regions $(>2100 \leq 2400)$ with a temperate warm class of viticultural climate (Tonietto and Carbonneau, 2004). According to Tonietto and Carbonneau, this class of viticultural climate is favourable for Grenache, Mourvèdre and Carignan grape varieties so there are no heliothermal limitations for the ripening of most grape varieties.

Night cold index for the Tri Morave wine region is $10.4{ }^{\circ} \mathrm{C}$ placing it into $\mathrm{CI}+2$ class of viticultural climate with very cool nights (Tonietto and Carbonneau, 2004). Considering that the importance of this index is related to determining the qualitative potential of vineyard areas in terms of secondary metabolites (polyphenols or aromas in grapes) meaning that it is an important factor related to colour and aromas in grapes and wine (Kliewer, Torres, 1972; Kliewer, 1973; Tomana et al., 1979), the Tri Morave wine region has a favourable Night cold index. Even though the effect of very low night temperatures depends on all climatic factors, the heliothermal potential in this case can secure good ripening of grapes. According to Tonietto and Carbonneau (2004), other regions with this class of viticultural climate include Alsace (France), Freiburg (Germany) and Santiago de Chile (Chile).

Dryness index for the Tri Morave wine region is $173.5 \mathrm{~mm}$ putting this region into DI-2 humid class of viticultural climate. Tonietto and Carbonneau (2004) describe this class of climate as the absence of drought with favourable water balance but with a tendency that excess water can negatively affect grape quality and the grapes ripen best in years with less rainfall during the period between April and September.

Temperature extremes. The number of days during the vegetation period with minimal daily temperatures equal to or less than $0^{\circ} \mathrm{C}$ is 5.5 which is very similar to most wine regions in Serbia. The number of days during the vegetation period with maximum daily temper- atures equal to or higher than $35^{\circ} \mathrm{C}$ is 4.9 , putting this region into areas with moderately high number of days with extremely high temperatures. The number of days during the dormancy period with minimal daily temperatures lower than or equal to $-15^{\circ} \mathrm{C}$ is 2.5 classifying this region as one with a medium number of days with extremely low temperatures (Jakšić, 2016).

All of the above parameters show that the Tri Morave wine region possesses favourable climatic conditions for vine growing and production of high quality grapes and wine. The main characteristic of the region is its warm climate but with very cool nights in September as well as the humidity during the period from April to September. All of this together creates the climatic specificity of this wine region which certainly affects the quality and characteristics of wine.

\section{Geomorphological and geological determinants of soil formation and soil types in the Tri Morave wine region}

Twelve out of sixteen basic elements for evaluating grapes intended for wine making are derived from different soil properties. Different soil characteristics such as soil depth, $\mathrm{pH}$ value, drainage, salinity, colour and texture of the soil can significantly affect grape quality. At the same time these soil properties hugely depend on local geomorphological and geological characteristics and their interaction with the vineyard soil and vines making it a crucial component of terroir (Burns, 2012).

The importance of mentioned factors does not only reflect in their direct impact on the quality and characteristics of wine because vines get most of the needed minerals and nutrients from a soil profile with a depth of up to $0.6 \mathrm{~m}$. At the same time, during a longer period, vines absorb water from the soil and parent substrate up to two meters deep. Only during dry periods, the subterranean waters play a role at depths larger than two meters (Marković, 1996). These facts clearly indicate that in areas where the soil profile is very deep, the direct impact of the geological base on vines is diminished (Huggett, 2006). However, the geological base and terrain relief in many areas where vines are grown have a big impact on grape quality through several properties: mineralogical structure, soil structure and texture, hydro-geological properties, susceptibility to erosion and other forms of soil degradation as well as modification of local and microclimatic conditions (Wilson et al., 1998; Cita et al., 2004; Cita, Fiore, 2006; Colacicchi, Parotto, 2006).

The geologic origin of the parental material of the soil has little direct influence on grape quality. Fine wines are produced from grapes grown on soils derived from all three basic rock types - igneous (derived from molten magma, e.g., granite), sedimentary 
(originating from consolidated sediments, e.g., shale, chalk, and limestone), or metamorphic (arising from transformed sedimentary rock, e.g., slate, quartzite, and schist). Examples of famed wine regions where the soils are primarily derived from a single rock type are Champagne and Chablis (chalk), Jerez (limestone), and Porto and Mosel (schist). However, equally famous regions have soils derived from a mixture of rock types, namely the Rheingau, Bordeaux, and Beaujolais (Wallace, 1972; Seguin, 1986; Jackson, 2008).

The Tri Morave wine region represents an area in which the most important rivers of Central Serbia meet: Južna and Zapadna Morava rivers, which together form the Velika Morava River. The main morphological features of this region are gentle relief contours rising above the alluvial plains of the three rivers across a series of fluvial terraces, gradually turning into mountainous areas. The south-west, southern and especially the western part of the region are much higher. The central part is dominated by Juhor Mountain with its highest peak Vetren (774 m). The southeast and north-east parts of the region are much lower and flatter as they gradually merge with the low hills in the valleys of Južna and Velika Morava rivers. This morphological asymmetry has led to the domination of very favourable combinations of exposure and terrain inclination which are suitable for vine cultivation. This kind of morphology provides adequate sun exposure, air circulation and soil drainage of vineyard surfaces and does not favour the emergence of extreme microclimatic conditions.

In the Tri Morave wine region we can clearly single out three basic geomorphological units: alluvial plains of the Južna, Zapadna and Velika Morava rivers, dissected fluvial terraces in the zone of low hills and the mountain zone. When it comes to vine growing, the most important zone is the one with fluvial terraces which are intersected with numerous valleys of smaller watercourses, mainly directed towards the alluvial plains of Južna, Zapadna and Velika Morava rivers as well as their main tributaries. A smaller number of vineyards are located in the mountains and only a few on the alluvial plains.

Apart from relatively simple geomorphological features, a turbulent and rich geological history caused a rich geodiversity in this region. On this relatively small area three out of four basic geotectonic units are present: Dinarides, Serbo-macedonian mass and the Carpatho-balkanides (Marović, 2001). During such a long geological evolution different rocks of Mesozoic and Cenozoic age were formed as well as numerous metamorphic and magmatic formations. Such a diverse geological structure has an impact on the modification of pedogenetic processess, affecting the appearance of specific types of soil.
In accordance with the region's geodiversity and regional and local specificities of the area, a matching soil covering was formed. The soil diversity is much larger in mountainous areas and in zones of alluvial plains. On the other hand, in the transitional geomorphological zone of fluvial relief a less expressed pedological diversity is present. The reason behind this is a more balanced structure of the parent substrate on which the soil was formed. The long term impact of fluvial processes in the region has led to the formation of different types of sedimentary rocks. Loess sediments of aeolian origin also represent a similar mixture of different minerals and are present as a parent substrate in this region. The presence of loess is however, much less than the dominating fluvial and colluvial sediments. Loess can be described as one of the best parent substrates for the formation of soil with potentially high fertility (Marković et al., 2015; Obreht et al., 2016). Such soils are important for the development of intensive agriculture and vine cultivation as well. Since the parent substrate represents an essential determinant of geo-chemical, mineralogical and granulometric properties of soils, the Tri Morave wine region has a moderate pedological diversity dominated by different varieties of only two types of soil: cambisols and vertisols.

Cambisols are relatively young and dynamical pedological formations. As a consequence of the parent substrate diversity and local edaphic factors there are many varieties of this type of soil in the Tri Morave wine region. These soils usually have brown or reddish colour and a typical structure. They are developed in middle and fine texture material which usually originates from different sedimentary rocks, mainly of alluvial, colluvial or aeolian origin (Miljković, 1996).

Most of these cambisol varieties have good properties for vine cultivation, primarily an adequate profile depth as well as favourable texture properties. A wellbalanced mechanical composition with a suitable ratio of fine and coarser fractions provides good conditions for vine root development. Good porosity and structure provide good water-air soil properties.

Vertisols are soils containing high levels of clay, especially montmorillonite originating from the parent substrate. This is the reason why these soils have high water-holding capacities. During the more humid part of the year there is an increase in the volume of the active part of the soil profile, and during more arid periods, when the water evaporates, deep cracks are formed through which the material from upper pedogenetic horizons constantly falls into the lower parts of the profile (Miljković, 1996).

Because of the mentioned unfavourable properties of the mechanical composition, vertisols have a lower total productive value for vine cultivation than camb- 
isols. However, the increased depth of the active part of the soil profile has a very favourable effect on the consistent presence of nutrients as well as acceptable water-air properties. Constant migration of minerals and nutrients provides stable physiological activities for the vines regardless of current climatic conditions (Miljković, 1996).

The duration of soil formation also represents an important pedogentic determinant. The age of certain soils of the investigated area, such as vertisols, can cover a significant time interval. This is why these older pedological formations can often have relict features and therefore a significantly deeper profile and a higher presence of clay as a consequence of a higher degree of decomposed primary minerals.

\section{Soil classification and soil properties in the Tri Morave wine region}

According to Rankine et al. (1971) and Wahl (1988), soil type appears to be among the least significant factors affecting grape and wine quality and wine characteristics (Morlat et al., 1983). The effect of soil is expressed indirectly through features such as heat retention, water holding capacity, and nutritional status. Factors like soil colour and textural composition affect heat absorption by the soil and, thereby, fruit ripening and frost protection. Thus, when discussing soil and its effects on grapevine growth, it is important to distinguish among the various physicochemical properties of soil - its texture, aggregate structure, nutrient availability, organic content, effective depth, $\mathrm{pH}$, drainage, and water availability. The uniformity of soil conditions is likely to be more important than any of these properties alone. Soil variability is a major source of asynchronous berry development, and lower wine quality (Jackson, 2008).

The soils which are present in this region are mainly vertisols (38.2 \%) and eutric cambisols (30.1\%). On some smaller areas fluvisols (7.1\%), podzols (6.6 \%), dystric cambisols (4.7 \%) and regosols (3\%) are also present. Besides these soils, other are also present in much smaller percentages (less than $3 \%$ ).

When it comes to physical properties of soils in the Tri Morave wine region, we can describe them as unfavourable. The values of soil density indicate the occurrence of increased soil compaction in surface horizons, which indicates an increased use of agricultural machinery. Almost $90 \%$ of investigated horizons have a density of $1.4 \mathrm{~g} / \mathrm{cm}_{3}$ which is unfavourable when it comes to water, air and thermal regime of the soil (Savin et al., 2004; 2009). If we take a look at soil porosity, we can notice that most of the investigated horizons belong to the class of weakly porous soils (Vasin, 2016). Soil permeability values are relatively favourable. However, they are not a result of oth- er favourable processes in the soil, but mainly a consequence of cracks due to swelling and contractions of clay minerals. A high content of the smallest mechanical element - clay, negatively affects the water, air and thermal regime of the soil. Vines react better to these conditions than most other plants, mainly because of a strong and deep root system.

Unfavourable physical properties can be reduced and corrected by choosing a better time for tillage and a less often use of agricultural machinery during the vegetative period. A balanced use of organic fertilizers can also improve the physical properties of the soil in this region (Vasin, 2016).

When it comes to chemical properties of soils there are several parameters which are of great importance for vine cultivation. The $\mathrm{pH}$ value of the soil has a big impact on vine and plant development as well as the speed and direction of chemical and biochemical processes in soils (Jakšić et al., 2013). The absorption of nutrients, the intensity of microbiological activity in the soil, mineralization of organic material, decomposition of soil minerals and hardly soluble compounds as well as other physical and chemical processes greatly depend on the soil $\mathrm{pH}$ value. The lack of many nutrients can be avoided if the $\mathrm{pH}$ value is between 6 and 7. Insufficiency or excess of certain nutrients is most common when the $\mathrm{pH}$ value is outside of these values (Dougherty, 2012). Lower $\mathrm{pH}$ values of soils are naturally more common and they originate from the $\mathrm{pH}$ values of the parent substrate on which the soil is formed. In older vineyards, $\mathrm{pH}$ values can be lower due to long-term inadequate use of acidic fertilizer.

According to Jakšić et al. (2016), in the Tri Morave wine region, the top layer of soil $(\mathrm{o}-30 \mathrm{~cm})$ has acidic $\mathrm{pH}$ value for the most part ( $72 \%$ of the regions surface area). Neutral $\mathrm{pH}$ values are present in $10 \%$ of the surface area while $9 \%$ is slightly acidic. Alkaline soils are present in $8 \%$ of the surface area while the percentage of highly acidic soils is $1 \%$. Liming measures are necessary on $62 \%$ of the regions surface area in order to raise the $\mathrm{pH}$ value. At depths of $30-60 \mathrm{~cm}$, the $\mathrm{pH}$ value is very similar to the surface layer $(0-30 \mathrm{~cm})$. Out of the total surface area, $63 \%$ is non-carbonate in the top layer of the soil $(0-30 \mathrm{~cm})$. Low carbonate soils make up about one third of the total surface area while medium and high carbonate soils are present at around 1 $\%$ of the surface area.

The content of humus in the soil is directly related to soil fertility. Soils containing larger amounts of humus are usually more fertile. Research by Jakšić et al. (2016) shows that the top layers $(0-30 \mathrm{~cm})$ contain poorer humic soils ( $68 \%$ of the total surface area). Humic soils occupy $30 \%$ while very poor humic soils only $2 \%$. At larger depths $(30-60 \mathrm{~cm})$ the amount of 
poorer humic soils is $70 \%$ while humic soils represent $20 \%$ and very poor humic soils $10 \%$. Very poor humic soils and poor humic soils require the use of organic fertilizer in order to increase the content of organic matter. Similar measures are needed on humic soils in order to maintain their fertility.

When it comes to the content of macro-elements (nitrogen, potassium and phosphorus), the content of nitrogen correlates highly positive with the content of humus which is quite expected as the mineralization of humus releases significant amounts of nitrogen. Looking at the content of potassium, the top layers of soil $(\mathrm{o}-30 \mathrm{~cm})$ show the following distribution: most part of the region ( $43 \%$ )has optimal levels, $22 \%$ has high levels, $18 \%$ has medium, $14 \%$ very high and $3 \%$ low levels. However, the deeper layers have a higher percentage of medium potassium levels (37\%), optimal (52\%) and low levels (10 \%) while surfaces with a high level occupy much less (1\%). Very high levels are not present at this depth. These results indicate that potassium fertilizers are needed at larger depths. The average content of potassium in the analyzed soils is $19.3 \mathrm{mg} \mathrm{K}_{2} \mathrm{O} / 100 \mathrm{~g}$ of soil, classifying them as soils with medium content (Jakšić et al., 2016).

The content of phosphorus in the soils is a bit unfavourable. Most of the regions area falls within the class of soils with very low phosphorus content. About $43 \%$ of the analyzed surfaces in the top layers (o-30 $\mathrm{cm})$ fall within this category as do $63 \%$ of surfaces at larger depths $(30-60 \mathrm{~cm})$ which is even more unfavourable since this soil layer is the zone of root system activity. The percentage of areas with low phosphorus content is much larger in deeper layers (about $1 / 3$ ) while the percentage of surfaces with medium levels is less ( $1 \%)$. Optimal and very high phosphorus content were not recorded at larger depths $(30-60 \mathrm{~cm})$. Low phosphorus content is a consequence of pedogenetic processes in the entire wine region. The formed soils were created on a parent substrate naturally poor in phosphorus (Jakšić et al., 2016). The use of fertilizer on the surface would not be sufficient due to the weak mobility of phosphorus along the profile. This is why fertilizer use is needed at larger depths. The application of combined phosphorus and organic fertilizers would enrich the soil with organic matter which would contribute to the transport of phosphorus to larger depths.

If we take a look at the content of micro-elements (copper, zinc, iron, manganese) in the soil, we can see that copper content varies from $0.7 \mathrm{mg} / \mathrm{kg}$ to $70.3 \mathrm{mg} /$ $\mathrm{kg}$. The average value of copper content is $9.2 \mathrm{mg} / \mathrm{kg}$. Based on these figures, the soils in the Tri Morave wine region have sufficient amounts of copper. The current zinc content is low. A little under $10 \%$ of the investigated area has less than $0.6 \mathrm{mg} / \mathrm{kg}$ of zinc. The highest recorded content was $9.7 \mathrm{mg} / \mathrm{kg}$ and the lowest $0.2 \mathrm{mg} / \mathrm{kg}$. Low zinc levels in these soils are a consequence of insufficient zinc in the parent substrate. When it comes to iron content, the amount of iron varies from $5.4 \mathrm{mg} / \mathrm{kg}$ to $106.9 \mathrm{mg} / \mathrm{kg}$ and the average value is $45.8 \mathrm{mg} / \mathrm{kg}$ meaning that the iron content in the soils is sufficient. The average content of manganese is $23 \mathrm{mg} / \mathrm{kg}$, varying from $2.7 \mathrm{mg} / \mathrm{kg}$ to $52.2 \mathrm{mg} /$ $\mathrm{kg}$ at some locations. Based on these figures, the soils in this region have sufficient amounts of copper (Va$\sin , 2016)$.

\section{Grape Varieties and wine production in the Tri Morave wine region}

The Tri Morave wine region has a wide range of grape varieties but it is mostly well-known for its black grape varieties used in production of high quality red, but also rosé wines. The most widespread black varieties are Cabernet Sauvignon and Merlot, followed by Prokupac (indigineous to Serbia), Frankovka, Pinot Noir and Vranac. Taking into account the climate and soil properties of the region for making red wines, this choice of grape varieties is quite logical.

When it comes to the production of white wines, Sauvignon Blanc is the most widespread variety followed by Riesling and Graševina. These varieties are an understandable choice since they possess certain resistance to low temperatures (Jakšić et al., 2007). Among the white varieties in this region there is also one more variety worth mentioning, the Tamjanika grape variety, native to Serbia (Jovanović et al., 2010). It is also among the top ten grapes planted in this region, with the Župa vineyard area producing most of the wine from this variety.

Wine production in over 70 market oriented wineries of this region represents a large production of wine in Serbia. Commercial wineries are mainly concentrated in the Župa, Kruševac, Jagodina, Rekovac and Trstenik vineyard regions while smaller wineries are present throughout the entire wine region (Jakšić et al., 2015). These smaller wineries are mainly oriented towards a more traditional way of producing wine, going back to their family roots and traditions with the main goal of producing smaller amounts of high quality wine (Jakšić et al., 2012). Accordingly, this wine region is one of the leading wine regions in the production of wines with GI. In the old GI system there are currently 10 wineries from this region: Budimir, Rajković, Spasić, Minić, Saboss, Botunjac, Ivanović, Đorđević, Rubin and Milosavljević. The first eight are located in the Župa vineyard region. These 10 wineries along with many others from the wine region are currently in preparation for the registration of the 'Tri Morave' indication under the new system of geographical indication in Serbia. 


\section{Conclusion}

The Tri Morave wine region is the largest wine region in Serbia. It is a region of red grape varieties for the production of high quality red and rosé wines. The share of red varieties in this region is almost two times bigger than the share of white grape varieties. The climatic conditions within the region are very suitable for vine growing and high quality grape and wine production. The main climate features of the region include warm temperatures but also very cool September nights as well as higher humidity from April to September. The vineyards of this region are located at higher altitudes than the average in Serbia which certainly influences grape ripening and wine quality and characteristics as well. Most of the vineyards are located on slopes ranging from gentle to very steep. This kind of terrain inclination together with sun exposure has a positive effect on thermal features as well as air and soil humidity. A high percentage of warmer and sunnier exposures where the vineyards are located indicates favourable topographical features of this region. All of these factors together form the specific terroir of this wine region affecting the quality and characteristics of wine produced in this region.

Over the past few years, terroir has become an important motive for travel when it comes to wine tourists. The growing presence of the term terroir and its concept in general throughout the wine world with the help of media and other means of informing has led to the fact that people no longer want to just try wines from certain regions at their home. They now wish to visit the places where those wines originate from and truly experience the space and taste of the place where that wine is produced. For example, some people have the need and desire to see the vineyards of Tuscany where the infamous Italian Brunello or Chianti originate from and about which they have heard so much and they enjoy drinking it. From this aspect, terroir plays an important role not only in the direct sale of certain wines but also in the increasing income from tourism travel and activities. This is very important especially for rural areas where many vineyards are located as such activities generate additional revenue and increase employment through tourism activities (Pivac, 2012). This form of tourism represents a good way of combating the effects of rural restructuring (Hall, Mitchell, 200o; Hall et al., 2000) which is present in many vineyard regions throughout the world as well as in parts of Serbia. Parallel with the development of this form of tourism, other complementary specific forms of tourism activities based on the evaluation of geographical space and cultural potentials can also be developed (Tomić, 2011; Solarska et al.,
2013; Tomić, Božić, 2014; Marković et al., 2014; Boškov et al., 2015; Božić, Tomić, 2015; Tomić et al., 2015).

Wine making and tourism co-exist for a long period of time and one of the main motives for visiting a wine region or a vinery is wine tasting together with a short story about that wine. Until recently, the more complex story of terroir has been more of a secondary motive for visit if at all but this is now slowly changing. The term terroir has become a kind of brand which the tourism industry has yet to make the most of in some places. The more and more demanding wine tourists and wine lovers are no longer fully satisfied with pure wine tastings. Nowadays, most of them know in advance what the wine is going to taste like because they have already tried it several times before. They now wish to hear a more detailed story of how this wine was actually created and what factors influenced in shaping it and giving it all of those unique aromas and such distinctive taste which are the main reasons why they enjoy drinking it that much. And that is actually the story of terroir.

\section{References}

Avramov, L. 1991. Viticulture. Nolit, Belgrade. (in Serbian)

Boškov, J., Kotrla, S., Tomić, N., Jovanović, M., Rvović, I. 2015. Perspectives for geotourism development in the Bela Crkva municipality (Serbia). Acta Geoturistica 6-1, 1-10.

Božić, S., Tomić, N. 2015. Canyons and gorges as potential geotourism destinations in Serbia: comparative analysis from two perspectives - general geotourists' and pure geotourists'. Open Geosciences 7, 531-546.

Burns, S. 2012. The importance of Soil and Geology in Tasting Terrior with Case History from Willamette Valley, Oregon. In: Dougherty P. [ed.]. The Geography of Wine: Regions, Terroir and Techniques. Springer, Dordrecht, The Netherlands

Cita, B. M., Colacicchi, R., Chiesa, S., Crisci, G. M., Massiotta, P., Parotto, M. 2004. Italian wines and geology. BE-MA editrice, Milan.

Cita, B. M., Fiore, A. 2006. Grape growing and wine making in two unique Italian terroirs: Teroldego Rotaliano and Aglianico del Vulture. Geoscience Canada Reprint, Series 9, 165-181pp.

Colacicchi, R., Parotto, M. 2006. Geologia dei vini italiani, Italia centrale. BE-MA editrice, Milan.

Dougherty, P. [ed.]. 2012. The Geography of Wine: Regions, Terroir and Techniques. Springer, Dordrecht, The Netherlands, $245 \mathrm{pp}$.

Hall, C. M., Sharples, L., Cambourne, B., Macionis, N. 200o. Wine Tourism Around the World. Butterworth - Heinemann, Oxford. 
Hall, C. M., Mitchell, R. 200o. Wine tourism in the Mediterranean: a tool for restructuring and development. Thunderbird International Business Reviews 42, 445-465.

Huggett, J. M. 2006. Geology and wine: a review. Proceedings of the Geologists' Association 117-2, 239-247.

Ivanišević, D., Jakšić, D., Korać, N. 2015. Atlas of Viticulture. Statistical Office of the Republic of Serbia, Belgrade. (in Serbian)

Jackson, R. 2008. Wine Science. Elsevier, Oxford, 751 pp.

Jakšić, D. 2016. Some Essential Characteristics of the Tri Morave Wine Region. In: Ninkov, J. [ed.]. Pedological and Agrochemical Properties of the Tri Morave Wine Region. Institute of Field and Vegetable Crops, Novi Sad. (in Serbian)

Jakšić, D., Žunić, D., Korać, N., Mandić, B., Golubović, M., Damljanović, N. 2007. Assessment of the resistance of some white wine varieties at low temperature. Zbornik naučnih radova sa XXII savetovanja „Unapređenje proizvodnje voća i grožđa“, Belgrade, Serbia 13-5, 97-102. (in Serbian)

Jakšić, D., Kuzmanović, J., Stojanović, V., Žunić, D., Todić, S., Jović, S. 2012.Trends in the development of modern Serbian viticulture and enology. Zbornik radova i apstrakata XIV Kongresa voćara i vinogradara Srbije sa međunarodnim učešćem. Vrnjačka Banja, Serbia. (in Serbian)

Jakšić, D., Ivanišević, D., Đokić, V., Brbaklić Tepavac, M. 2015.Wine Atlas. Statistical Office of the Republic of Serbia, Belgrade. (in Serbian)

Jakšić, S., Vučković, S., Vasiljević, S., Grahovac, N., Popović, V., Šunjka, D., Dozet, G. 2013. Accumulation of heavy metals in Medicago sativa L. and Trifolium pratense L. on contaminated fluvisols. Hemijska industrija 67-1, 95-101. (in Serbian)

Jakšić, S., Milić, S., Ninkov, J. 2016. Essential chemical properties of soil. In: Ninkov, J. [Ed.]. Pedological and Agrochemical Properties of the Tri Morave Wine Region. Institute of Field and Vegetable Crops, Novi Sad (in Serbian)

Jones, G. V., Goodrich, G. B. 2008. Influence of Climate Variability on Wine Region in the Western USA and on Wine Quality in the Napa Valley. Climate Research 35, 241-254.

Jovanović, Z., Garić, M., Ćirković, B. 2010. Effect of pruning on yield and quality of white Tamjanika grapes in Župa vineyards. Agroznanje 11-2, 93-99. (in Serbian)

Kliewer, W. M., Torres, R.E. 1972. Effect of controlled day and night temperatures on grape coloration. American Journal of Enology and Viticulture 2, 71-77.

Marović, M. 2001. Geology of Yugoslavia. University of Belgrade, Faculty of Mining and Geology, Belgrade.
Marković, S. B. 1996.Water regime and flow direction of phreatic groundwater in the Yugoslavian part of Banat. University of Novi Sad, Faculty of Science, Institute of Geography, Novi Sad.

Marković, S. B., Korać, M., Mrđić, N., Buylaert, J-P., Thiel, C., McLaren, S. J., Stevens, T., Tomić, N., Petić, N., Jovanović, M., Vasiljević, Dj. A., Sümegi, P., Gavrilov, M. B., Obreht, I. 2014. Palaeoenvironment and geoconservation of mammoths from the Nosak loess-palaeosol sequence (Drmno, Northeastern Serbia): Initial results and perspectives. Quaternary International 334-335,30-39.

Marković, S., Stevens, T., Kukla, G. J., Hambach, U., Fitzsimmons, K. E., Gibbard, P., Buggle, B., Zech, M., Guo, Z. T., Hao, Q. Z., Wu, H., O’Hara-Dhand, K., Smalley, I. J., Ujvari,G., Sümegi, P., Timar-Gabor, A., Veres, D., Sirocko, F., Vasiljević, Đ., Jari, Z., Svensson, A., Jović, V., Kovács, J., Svirčev, Z. 2015. The Danube loess stratigraphy - new steps towards the development of a pan-European loess stratigraphic model. Earth Science Reviews 148, 228-258.

Miljković, N. S. 1996. Fundamentals of soil science. University of Novi Sad, Faculty of Science, Institute of Geography, Novi Sad.

Morlat, R., Asselin, C., Pages, P., Leon, H., Robichet, J., Remoue, M., Salette, J., Caille, M. 1983. Integrated characterization of some terroirs of the Loire Valley and the influence on the quality of the wines. Vigne Vin 17, 219-246. (in French)

Nakalamić, A., Marković, N. 2009. General Viticulture. Vizartis, Belgrade. (in Serbian)

Obreht, I., Zeeden, C., Hambach, U., Veres, D., Marković, S.B, Bösken, J., Svirčev, Z., Bačević, N., Gavrilov, M.B., Lehmkuhl, F. 2016. Tracing the influence of Mediterranean climate on Southeastern Europe during the past 350,000 years. Scientific Reports 6,36334 .

Pivac, T. 2012.Wine Tourism in Vojvodina. University of Novi Sad, Faculty of Science, Department of Geography, Tourism and Hotel Management, Novi Sad. (in Serbian)

Rankine, B.C., Fornachon, J.C.M., Boehm, E.W., Cellier, K.M. 1971. Influence of grape variety, climate and soil on grape composition and on the composition and quality of table wines. Vitis 10, 33-50.

Resolution of International Organisation of Vine and Wine OIV/VITI 333/2010. Definition of vitivinicultural "Terroir". The General Director of the OIV, General assembly Tbilisi Georgia, 25th June 2010.

Savin, L., Furman, T., Vasin, J., Hadžić, V. 2004. Analysis of the impact of soil compaction on maize and wheat yield on headland. Traktori i pogonske mašine 9-4, 93-98. 
Savin, L., Nikolić, R., Simikić, M., Furman, T., Tomić, M., Gligorić, R., Jarak, M., Đurić, S., Sekulić, P., Vasin, J. 2009. Influence of soil compaction on changes in soil and sunflower yield. Savremena poljoprivredna tehnika 35-1-2, 26-32.

Seguin, G. 1986. Terroirs and pedology of wine growing. Journal of Biological Chemistry 42, 861-873.

Solarska, A., Hose, T. A., Vasiljević, Dj. A., Mroczek, P., Jary, Z., Marković, S. B., Widawski, K. 2013. Geodiversity of the loess regions in Poland: Inventory, geoconservation issues, and geotourism potential. Quaternary International 296, 68-81.

Stojanović, M., Toskić, V. 1948.Viticulture. Naučna knjiga, Belgrade. (in Serbian)

Tomana, T., Utsunomiya, N., Dataoka, I. 1979. The effect of environmental temperatures on fruit on ripening on the tree. Journal of the Japanese Society for Horticultural 48-3. 261-266.

Tomić, N. 2011. The Potential of Lazar Canyon (Serbia) as a Geotourism Destination: Inventory and Evaluation. Geographica Pannonica 15-3, 103-112.

Tomić, N., Božić, S. 2014. A modified geosite assessment model (M-GAM) and its application on the Lazar Canyon area (Serbia). International Journal of Environmental Research 8-4, 1041-1052.

Tomić, N., Marković, S. B., Korać, M., Mrđić, N., Hose, T. A., Vasiljević, Dj. A., Jovičić, M., Gavrilov, M. B. 2015. Exposing mammoths - from loess research discovery to public palaeontological park. Quaternary International 372,142-150.

Tonietto, J., Carbonneau, A. 1999. Global analysis of the climate of the wine regions and their influence on the typicality of wines: the position of Brazilian viticulture compared to 100 regions in 30 countries. In: Tonietto, J., Guerra, C. C. [eds.]. Annals of the Brazilian Congress of Viticulture and Oenology, Embrapa Grape and Wine. Bento Gonçalves, Portugal. (in Portugese)

Unwin, T. 2012. Terroir: at the heart of geography. In: Dougherty, P. H. [ed.]. The Geography of wine. Springer, Dordrecht, The Netherlands.

Vasin, J. 2016. Physical and water-physical properties of soil. In: Ninkov, J. [ed.]. Pedological and Agrochemical Properties of the Tri Morave Wine Region. Institute of Field and Vegetable Crops, Novi Sad. (in Serbian)

Wahl, K. 1988. Climate and soil effects on grapevine and wine. The situation on the northern borders of viticulture - the example of Franconia. Proceeding of the 2nd International Symposium for Cool Climate Viticulture and Oenology. New Zealand Society of Viticulture and Oenology, Auckland, New Zealand.

Wallace, P. 1972. Geology of wine. In: Gill, J. E. [ed.]. Proceeding of the 24th International Geology Congress, Montreal, Canada.

Wilson, J. E. 1998. Terroir: The Role of Geology, Climate and Culture in the Making of French Wines. University of California Press, USA.

Winkler, A. J., Cook, J. A., Kliwer, W. M., Lider, L. A. 1974. General viticulture. University of California Press, USA. 